\title{
Integrin Alpha-IIb/Beta-3
}

National Cancer Institute

\section{Source}

National Cancer Institute. Integrin Alpha-IIb/Beta-3. NCI Thesaurus. Code C77161.

Integ rin alpha-IIb/beta3 is a protein complex comprised of a heterodimer of integ rin alpha $2 \mathrm{~b}$ and integ rin beta 3 . This complex is involved in cell adhesion and blood clot formation. 